\title{
Influence of feeding regimen and protein supplementation on the sites of net absorption of magnesium in sheep
}

\author{
By N. D. GRACE AND J. C. MACRAE \\ Applied Biochemistry Division, DSIR, Palmerston North, New Zealand \\ (Received 28 October 1970-Accepted 24 May I971)
}

\begin{abstract}
I. Sheep prepared with a rumen cannula and with re-entrant cannulas at the proximal duodenum and terminal ileum were given diets of dried grass, and dried grass supplemented with formalin-treated or untreated casein. They were fed either continuously or once daily. Paper impregnated with chromic oxide was given once daily via the rumen fistula.

2. The observed daily flows of magnesium at the duodenum and ileum were highly correlated with the corresponding flows of $\mathrm{Cr}$.

3. There was a net absorption of $\mathrm{Mg}$ from the stomach as well as the intestinal region of all sheep.

4. Protein supplementation had no effect on the extent or sites of Mg absorption, but altering the feeding regimen changed the proportions of the net absorption of $\mathrm{Mg}$ occurring in the stomach and intestinal regions.
\end{abstract}

From earlier studies on magnesium absorption from the digestive tract of ruminants it was concluded that the intestinal region, particularly the small intestine, was the most important site of $\mathrm{Mg}$ absorption (Stewart \& Moodie, 1956; Phillipson \& Storry, 1965; Care \& van't Klooster, I965; Scott, I965). However, recent reports have suggested that net absorption of $\mathrm{Mg}$ occurs from the stomach region of cattle (Rogers \& van't Klooster, I969) and sheep (Pfeffer, Thompson \& Armstrong, 1970).

It has also been reported that plant constituents, such as crude protein, appear to affect the absorption of $\mathrm{Mg}$ from the digestive tract of sheep (Stillings, Bratzler, Marriott \& Miller, 1964) and cattle (Kemp, Deijs, Hemkes \& van Es, 196r). The apparent availability of $\mathrm{Mg}$ decreases as the crude protein concentration of the herbage increases.

In the course of a study designed mainly to investigate the digestion by sheep of formalin-treated and untreated casein supplements (MacRae, Ulyatt, Pearce \& Hendtlass, 1972) we have examined the possible effects of feeding regimen and protein supplementation on the sites of net absorption of $\mathrm{Mg}$. A preliminary report of part of this work has been given (Grace, I970).

\section{EXPERINENTAL}

Sheep. Castrated male Romney Marsh sheep, I-2 years old and weighing 40-45 kg, were each prepared with a rumen cannula and with re-entrant cannulas in the proximal duodenum and terminal ileum (Brown, Armstrong \& MacRae, r968). They were kept in metabolism crates, under continuous artificial light and constant temperature $\left(15-18^{\circ}\right.$ ), and had free access to tap-water. $M g$ intake from this source at no time exceeded $6 \mathrm{mg} / 24 \mathrm{~h}$. 
Experimental design. The experiments conducted were those described by MacRae et al. (1972) in which diets of dried grass, dried grass plus formalin-treated casein and dried grass plus untreated casein were given from continuous-belt feeders (Sutherland, Gupta, Reid \& Murray, 1964). Later the daily rations of dried grass and dried grass plus treated casein were given once daily at 09.00 hours. Details of the diets given and the sheep used in the experiments with continuous feeding have been given previously (MacRae et al. 1972, Table I). When the diets were given once daily, three sheep were given each diet, and two $24 \mathrm{~h}$ duodenal collections and one $7 \mathrm{~d}$ faecal collection were made from each sheep.

The dried grass contained, on a dry-matter basis, $2 \cdot 65 \% \mathrm{~N}$ and $0.21 \% \mathrm{Mg}$ and had a digestibility coefficient for dry matter of 74.4 . The treated and untreated casein preparations contained $14.6 \% \mathrm{~N}$ and $15.2 \% \mathrm{~N}$ respectively; both preparations contained $0.014 \% \mathrm{Mg}$.

Marker. Chromic oxide, in the form of $6 \mathrm{~g}$ pellets of paper impregnated with chromic oxide, was administered via the rumen cannula to all sheep daily at 09.00 hours. From the faecal excretion values it was calculated that these pellets supplied $\mathrm{I} \cdot 16_{3} \pm 0.017 \mathrm{~g}$ of Cr daily (MacRae et al. 1972).

Collection, preparation and analysis of samples. The techniques used for the collection and preparation of food, faeces and $24 \mathrm{~h}$ duodenal and ileal samples from each sheep have been fully outlined by MacRae et al. (1972). Mg was determined in the food, dudenal, ileal and faecal samples by atomic absorption after ashing at $500^{\circ}$ and extracting in $\mathrm{I} 2 \mathrm{M}$ - and $2 \mathrm{M}-\mathrm{HCl}$. $\mathrm{Cr}$ was also determined by atomic absorption in the duodenal, ileal and faecal samples by the method of Williams, David \& Iismaa (1962).

\section{RESULTS}

Relationships between $24 \mathrm{~h}$ flows of $\mathrm{Mg}$ and $\mathrm{Cr}$. The relationship between the $24 \mathrm{~h}$ flows of $\mathrm{Mg}$ and $\mathrm{Cr}$ was investigated to validate the assumption that it is possible to correct observed daily flows of $\mathrm{Mg}$ to average $24 \mathrm{~h}$ values by use of $\mathrm{Cr}$ recovery (see MacRae \& Armstrong, 1969; MacRae et al. 1972).

Table $\mathrm{I}$ shows the correlation coefficients and regression equations for the observed $24 \mathrm{~h}$ flows of $\mathrm{Mg}$ and $\mathrm{Cr}$. The correlation coefficients at both the duodenum and the ileum with continuous feeding were highly significant $(P<0.01)$ whilst that at the duodenum with once-daily feeding was significant $(P<0.03)$.

Flow of $M g$ through the digestive tract. The mean observed and adjusted $24 \mathrm{~h}$ flows of $\mathrm{Mg}$ through the digestive tract of sheep given diets of dried grass and dried grass supplemented with casein or formalin-treated casein, given continuously or once daily, are given in Table 2.

Effect of feeding regimen. Although changing the feeding regimen had almost no effect on the total net absorption of $\mathrm{Mg}$ from the digestive tract, it did alter the relative importance of the stomach and intestinal regions as sites of net absorption of $\mathrm{Mg}$. With continuous feeding about $94 \%$ of the net absorption of $\mathrm{Mg}$ occurred in the stomach region compared with only $50 \%$ with once-daily feeding.

On continuous feeding a statistically significant but extremely variable (individual 
within-animal values ranged from 0.0 I to $0.23 \mathrm{~g} / 24 \mathrm{~h}$ ) net secretion of $\mathrm{Mg}$ was observed in the small intestine and a net absorption of $\mathrm{Mg}$ was observed from the large intestine. The ileal flows were not studied with once-daily feeding. However, there was a greater net absorption of $\mathrm{Mg}$ from the intestines of sheep given food once daily compared to those given food continuously.

Effect of protein supplement. The addition of protein supplements, available to the sheep either mainly in the rumen (untreated casein) or mainly beyond the rumen

Table r. Relationships of the observed 24 flows of magnesium to the corresponding observed 24 hlows of chromium at the duodenum and at the ileum of sheep fed continuously and at the duodenum of sheep fed once daily on $900 \mathrm{~g}$ of dried grass

\begin{tabular}{|c|c|c|c|c|}
\hline & $\begin{array}{l}\text { No. of } \\
\text { sheep }\end{array}$ & $\begin{array}{l}\text { No. of } \\
\text { collections }\end{array}$ & Regression equation & $\begin{array}{l}\text { Correlation } \\
\text { coefficient }\end{array}$ \\
\hline \multicolumn{5}{|c|}{ Continuous feeding } \\
\hline $\begin{array}{l}\text { Duodenum } \\
\text { Ileum }\end{array}$ & $\begin{array}{l}5 \\
6\end{array}$ & $\begin{array}{l}\text { 10 } \\
\text { II }\end{array}$ & $\begin{array}{l}\operatorname{Mg}(g / 24 \mathrm{~h})=0.039+(0.90 \pm 0.09) \mathrm{Cr}(\mathrm{g} / 24 \mathrm{~h}) \\
\operatorname{Mg}(\mathrm{g} / 24 \mathrm{~h})=0.186+(0.89 \pm 0.19) \mathrm{Cr}(\mathrm{g} / 24 \mathrm{~h})\end{array}$ & $\begin{array}{l}0.95^{* * *} \\
0.85^{* *}\end{array}$ \\
\hline & & & Once-daily feeding & \\
\hline Duodenum & 3 & 6 & $\operatorname{Mg}(g / 24 h)=0.24+(0.97 \doteq 0.05) \mathrm{Cr}(g / 24 h)$ & $0.86^{*}$ \\
\hline
\end{tabular}

Table 2. Comparison of quantities of magnesium flowing through the digestive tract of sheep given diets of dried grass and dried grass supplemented with treated or untreated casein continuously or once daily

(Adjusted flows of $\mathrm{Mg}$ at the duodenum and ileum have been calculated on the basis of 100\% recovery of $\mathrm{Cr}$. Values for the percentage of the net absorption of $\mathrm{Mg}$ occurring in the stomach and intestinal regions are also given. Values in parentheses are the numbers of separate $24 \mathrm{~h}$ duodenal and ileal collections used to give the mean values with their standard errors)

\begin{tabular}{|c|c|c|c|c|c|}
\hline & \multicolumn{3}{|c|}{ Continuous feeding } & \multicolumn{2}{|c|}{ Once-daily feeding } \\
\hline & $\begin{array}{c}\text { Without } \\
\text { supplement }\end{array}$ & $\begin{array}{l}\text { With } 60 \mathrm{~g} \\
\text { treated casein }\end{array}$ & $\begin{array}{l}\text { With } 60 \mathrm{~g} \\
\text { untreated casein }\end{array}$ & $\begin{array}{l}\text { Without } \\
\text { supplement }\end{array}$ & $\begin{array}{l}\text { With } 60 \mathrm{~g} \\
\text { untreated casein }\end{array}$ \\
\hline Food $(g / 24 h)$ & $x \cdot 67$ & $\mathrm{I} \cdot 68$ & $x \cdot 68$ & $1 \cdot 67$ & $\mathrm{I} .68$ \\
\hline \multicolumn{6}{|l|}{ Duodenum $(\mathrm{g} / 24 \mathrm{~h})$} \\
\hline Observed & $0.90 \pm 0.05(10)$ & $0.82 \pm 0.04(7)$ & $0.89 \pm 0.04(6)$ & I.06 $\pm 0.07(6)$ & $I \cdot 08 \pm 0.0 I(6)$ \\
\hline Cr-adjusted & $x \cdot 09 \dagger \pm 0.03$ & $1 \cdot 07 \uparrow \pm 0.05$ & $I \cdot 06 \dagger \pm 0.02$ & $I \cdot 36 \pm \pm 0.06$ & $I \cdot 43 \ddagger+0.03$ \\
\hline \multicolumn{6}{|l|}{$\operatorname{lleum}(\mathrm{g} / 24 \mathrm{~h})$ : } \\
\hline Observed & $\mathbf{x} \cdot 0 \mathrm{I} \pm 0.09$ (I I) & $0.86 \pm 0.06(5)$ & $0.83 \pm 0.08(7)$ & ND & ND \\
\hline Cr-adjusted & $I \cdot 17 \pm 0.03$ & $I \cdot 24 \pm 0.06$ & $1 \cdot 24 \pm 0 \cdot 02$ & & \\
\hline Facces $(\mathrm{g} / 24 \mathrm{~h})$ & $1.04 \pm 0.02$ & $I .04 \pm 0.05$ & $I .05 \pm 0.02$ & $I \cdot 05 \pm 0.02$ & $1.08 \div 0.06$ \\
\hline $\begin{array}{l}\text { Apparent availability } \\
(\%)\end{array}$ & $3^{8}$ & $3^{8}$ & ${ }_{3} 8$ & 37 & 36 \\
\hline \multicolumn{6}{|l|}{$\begin{array}{l}\text { Net } \mathrm{Mg} \text { absorption } \\
\text { occurring: }\end{array}$} \\
\hline $\begin{array}{l}\text { In stomach region } \\
(\%)\end{array}$ & 89 & 95 & $9^{8}$ & 50 & 42 \\
\hline $\begin{array}{l}\text { In intestinal } \\
\text { region }(\%)\end{array}$ & I I & 5 & 2 & 50 & 58 \\
\hline
\end{tabular}

†† The adjusted $\mathrm{Mg}$ flows with different superscripts are significantly different $(P<0.0 \mathrm{I})$. ND, not determined. 
(treated casein) (see MacRae et al. 1972), had no effect on the apparent availability of the $\operatorname{Mg}(38 \%)$ of the dried grass.

There was no interaction between the feeding regimen and supplementation with protein (untreated casein).

\section{DISCUSSION}

MacRae et al. (1972) showed that in sheep given dried grass there were highly significant $(P<0.0 \mathrm{I})$ relationships between the observed $24 \mathrm{~h}$ flows of $\mathrm{Cr}$ and the corresponding flows of organic constituents past the duodenal and ileal cannulas. They concluded that it is valid to adjust the flows of organic constituents to mean $24 \mathrm{~h}$ values on the basis of $100 \%$ recovery of $\mathrm{Cr}$. The relationship found between the $24 \mathrm{~h}$ flow of $\mathrm{Mg}$ and corresponding flow of $\mathrm{Cr}$ under the two feeding regimens indicates that it is valid to adjust $\mathrm{Mg}$ flows also on the basis of $100 \%$ recovery of $\mathrm{Cr}$. Further, substituting $\mathrm{x} \cdot \mathrm{r} 63 \mathrm{~g} \mathrm{Cr} / 24 \mathrm{~h}$ in the regression equations (see Table $\mathrm{I}$ ) of $\mathrm{Mg}$ on $\mathrm{Cr}$, the calculated values for the adjusted flow of Mg past the duodenum and ileum of sheep fed continuously and past the duodenum of sheep fed once daily are $\mathrm{I} \cdot 09, \mathrm{I} \cdot 22$ and $\mathrm{r} \cdot 38 \mathrm{~g} / 24 \mathrm{~h}$. These values are similar to the values given in Table 2 , namely $\mathrm{r} \cdot 09, \mathrm{r} \cdot \mathrm{I} 7$ and $\mathrm{I} \cdot 36 \mathrm{~g} / 24 \mathrm{~h}$, obtained by simple arithmetical adjustment of individual observations.

The net absorption of $\mathrm{Mg}$ from the stomach region which was observed in all sheep in this study confirms the earlier findings of Pfeffer et al. ( 1970 ) in sheep and Rogers \& van't Klooster ( 1969 ) in cattle. However, the design of the present experiments and the conflicting evidence from earlier studies make it difficult to speculate as to which compartment of the stomach is the major site of Mg absorption. Some of the earlier workers, using various experimental techniques, have demonstrated an absorption of $\mathrm{Mg}$ from the reticulo-rumen (Stewart \& Moodie, 1956; Care \& van't Klooster, 1965) and abomasum (Stewart \& Moodie, 1956) while others have not (Phillipson \& Storry, 1965). Further, Rogers \& van't Klooster(1969) have suggested that the omasum might be an important site of $\mathrm{Mg}$ absorption.

The net secretion of $\mathrm{Mg}$ into and net absorption of $\mathrm{Mg}$ from the small and large intestine respectively observed in this study also confirm the findings of Pfeffer $e t a l$. (1970) for sheep and Rogers \& van't Klooster (1969) for cattle. Although earlier studies (Stewart \& Moodie, 1956; Scott, 1965) reported an absorption of Mg from the small intestine, in our investigation the Mg entering this region via endogenous secretions (Storry, 1961) evidently exceeded that being absorbed.

The feeding regimen had a marked effect on the relative importance of the stomach and intestinal regions in terms of the net absorption of Mg. The cause(s) of this difference was not established. However, two possible contributing factors could be changes in the rates of secretions of saliva and gastric juices, and changes in the diurnal flow of digesta from this region.

Storry (1961) estimated that $200 \mathrm{mg}$, or about $80 \%$, of the $\mathrm{Mg}$ secreted into the digestive tract enters via the salivary and gastric secretions. If the absolute absorption of $\mathrm{Mg}$ from the stomach region was not changed with feeding regimen, but there was an increase in the secretion of $\mathrm{Mg}$ into the stomach region as a result of once-daily feeding, then this could explain in part the observed decrease in the net absorption of $M g$ from this region. On the other hand, it has been observed (Harris \& Phillipson, 
1962) that with twice-daily feeding two broad pulses of digesta enter the small intestine some 8- $12 \mathrm{~h}$ after each meal, whereas with continuous feeding the flow of digesta is relatively constant (MacRae \& Ulyatt, unpublished). It is reasonable to assume that a pulse would also occur with once-daily feeding, during which the quantity of $\mathrm{Mg}$ passing through the stomach might possibly have been increased to such an extent that the opportunity for absorption from this region was limited.

It has been reported that when the crude protein content of fresh herbage given to cattle is progressively increased from $14 \%$ to $26 \%$ the apparent availability of the $\mathrm{Mg}$ decreased from $20 \%$ to $10 \%$ (Kemp et al. 1 $96 \mathrm{r}$ ). Further, in sheep given dried forage, an increase of dietary crude protein from $16 \%$ to $27 \%$ also decreased the availability of $\mathrm{Mg}$ from $24 \%$ to $16 \%$ (Stillings et al. 1964). These observations have led to the suggestion that the availability of $\mathrm{Mg}$ in pasture containing high concentrations of crude protein may be considerably reduced (Metson, Saunders, Collie \& Graham, 1966). In our experiments, increasing the level of dietary protein from $16.5 \%$ to $21.5 \%$ by means of casein supplements had no effect on the apparent availability or net absorption of $\mathrm{Mg}$ from the digestive tract of sheep given dried grass. Consequently it would appear that the fall previously reported in the apparent availability of $\mathrm{Mg}$ when the crude protein concentrations of the herbage are increased may not be explained solely on the grounds of interactions occurring within the digestive tract of ruminants as a result of increasing the dietary protein intake. It is probable, therefore, that the observed decreases are due to other herbage factors which are altered as the concentration of crude protein increases.

It is obvious that further investigations will have to be undertaken to confirm our observations, to define more fully the sites of $\mathrm{Mg}$ absorption and to understand the effect that factors such as diet and feeding regimen may have on the absorption of $\mathrm{Mg}$.

The authors wish to acknowledge the skilled assistance of Dr M. J. Ulyatt and Messrs A. King, S. Pickmere, D. Shelton and P. Vlieg during the collection of intestinal samples and of Mr A. King and Mrs P. Cooper during the subsequent analytical programme.

\section{REFERENCES}

Brown, G. F., Armstrong, D. G. \& MacRae, J. C. (1968). Br. vet. F. 124, 78.

Care, A. D. \& van't Klooster, A. Th. (1965). $\%$. Physiol., Lond. r77, 174.

Grace, N. D. (1 970). Proc. N.Z. Soc. Anim. Prod. 30, 2 I.

Harris, L. E. \& Phillipson, A. 'T. (Ig6z). Anim. Prod. 4, 97.

Kemp, A., Deijs, W. B., Hemkes, O. J. \& van Es, A. J. H. (1961). Neth. F. agric. Sci. 9, 134.

MacRae, J. C. \& Armstrong, D. G. (1969). Br. F. Nutr. 23, I5.

MacRae, J. C., Ulyatt, M. J., Pearce, P. D. \& Hendtlass, J. (1972). Br. F. Nutr. 27, 39.

Metson, A. J., Saunders, W. M. H., Collie, T. W. \& Graham, V. W. (I966). N.Z. fl agric. Res. 9, 410.

Pfeffer, E., Thompson, A. \& Armstrong, D. G. (1970). Br. F. Nutr. 24, 197.

Phillipson, A. T. \& Storry, J. E. (1965). F. Physiol., Lond. I81, I 30.

Rogers, P. A. M. \& van't Klooster, A. Th. (1969). Meded. LandbHoogesch., Wageningen 69, I r.

Scott, D. (ro65). Q. Jl exp. Physiol. 50, 312.

Stewart, J. \& Moodie, E. W. (I956). F. comp. Path. 66, 10.

Stillings, B. R., Bratzler, J. W., Marriott, L. F. \& Miller, R. C. (1964). F. Anim. Sci. 23, I 48.

Storry, J. E. (196r). Nature, Lond. r9o, 1 197.

Sutherland, T. M., Gupta, B. N., Reid, R. S. \& Murray, M. G. (1964). Proc. int. Congr. Nutr. vi. Edinburgh I 963 , p. 579 .

Williams, C. H., David, D. J. \& Iismaa, O. J. (1962). F. agric. Sci., Camb. 59, 38 r. 